\title{
Oblicza dialogu wychowawczego w świetle adhortacji apostolskiej Familiaris consortio a wychowanie w rodzinie
}

W wychowaniu bowiem chodzi właśnie o to, aby człowiek stawał się bardziej człowiekiem ${ }^{1}$ (Jan Paweł II).

Według powszechnie przyjętej nauki katolickiej, sformułowanej w wypowiedziach wielu papieży i orzeczeniach soborowych (lyoński II, florencki, trydencki, watykański II) ${ }^{2}$, „małżeństwo między ochrzczonymi jest jednym z siedmiu sakramentów Nowego Przymierza"'3. Po zawarciu sakramentalnego małżeństwa, dwoje ludzi rozpoczyna swą codzienną wędrówkę ku pełnemu objawieniu i realizacji królestwa Bożego ${ }^{4}$. Wówczas rodzina „staje się pierwszą i niezastąpioną szkołą życia społecznego, przykładem oraz bodźcem do szerszych kontaktów społecznych w duchu szacunku, dialogu i miłości"s. Wspólnotowość i uczestnictwo rodziny przeżywane na co dzień w rodzinnym domu w trudnościach i radościach stanowią o najlepszej i najskuteczniejszej pedagogii w odpowiedzialnym formowaniu dzieci do zadań społecznych ${ }^{6}$.

Warto w tym miejscu przytoczyć słowa ks. J. Tischnera, który stwierdza, że

spotkanie człowieka z człowiekiem niesie za sobą taką siłę perswazji, że zdolna jest zmienić radykalnie stosunek człowieka do otaczającego świata, ukształtować na nowo sposób bycia człowieka w tym świecie, zakwestionować uznawaną dotychczas hierarchię wartości. Spotkanie

${ }^{1}$ Jan Paweł II, Słowa wypowiedziane 2 VI 1980 r. w paryskiej siedzibie UNESCO.

${ }^{2}$ A. L. Szafrański, Małżeństwo i rodzina w świetle nauki kościoła i współczesnej teologii, Lublin 1985, s. 57.

${ }^{3}$ DS 971, 1001, 1797-1812.

${ }^{4}$ Por. Jan Paweł II, Adh. Familiaris consortio, 65 (dalej: FC).

${ }^{5} \mathrm{FC} 43$.

${ }^{6}$ Por. FC 37. 
wprowadza człowieka w głąb wielkich tajemnic istnienia, gdzie rodzą się pytania o sens i bezsens wszystkiego, co jest ${ }^{7}$.

Proces wychowania jest nierozerwalnie związany z komunikacją, dialogiem, dlatego też warto podkreślić, iż pragnienie komunikacji i przyjaźni jest zakorzenione w ludzkiej naturze, a dialog wychowawczy ma służyć gromadzeniu ludzkości w jedną rodzinę ${ }^{8}$.

\section{Apostolskie posłannictwo rodziny}

Tworzenie nowego społeczeństwa, które kieruje się prawdami Bożymi w życiu wspólnym, staje się owocem apostolskiej misji rodziny. To apostolskie posłannictwo rodziny jest ,zakorzenione w chrzcie świętym, a przez łaskę sakramentu małżeństwa otrzymuje nową moc dla przekazywania wiary, dla uświęcenia i przemiany współczesnego społeczeństwa wedle zamysłu Bożego"".

„Rodzina jako taka otrzymała od Boga posłannictwo, by stać się pierwszą i żywotną komórką społeczeństwa. Wypełni ona to posłannictwo, jeżeli przez wzajemną miłość swych członków i przez modlitwę wspólnie zanoszoną do Boga okaże się niejako domowym sanktuarium Kościoła, jeżeli cała rodzina włączy się w kult liturgiczny, świadczyć będzie miłosierdzie i popierać sprawiedliwość oraz inne dobre uczynki służące wszystkim braciom znajdującym się w potrzebie"10. Idea rodziny jako domowego Kościoła została wydobyta i mocno zaakcentowana w dokumentach soboru watykańskiego II i w nauczaniu ostatnich papieży. Ideę tę poruszali także we wcześniejszych wiekach wielcy teologowie i święci ${ }^{11}$.

Jan Paweł II wskazał na powiązania między Eucharystią i małżeństwem:

Eucharystia jest samym źródłem małżeństwa chrześcijańskiego. Ofiara eucharystyczna bowiem uobecnia przymierze miłości Chrystusa z Kościołem, przypieczętowane Jego krwią na krzyżu (por. J 19,34). W tej właśnie ofierze Nowego i Wiecznego Przymierza małżonkowie chrześcijańscy znajdują korzenie, z których wyrasta, stale się odnawia i nieustannie ożywia ich przymierze małżeńskie ${ }^{12}$.

${ }^{7}$ M. Śnieżyński, Od monologu do dialogu edukacyjnego, [w:] Wychowanie na rozdrożu. Personalistyczna filozofia wychowania, red. F. Adamski, Kraków 1999, s. 61.

${ }^{8}$ W. Kądziołka, Warto rozmawiać, czyli o komunikacji jako czynniku gwarantujacym powstanie grupy, ,Studia nad Rodziną” 26-27 : 2010, s. 253.

${ }^{9}$ FC 52.

${ }^{10}$ Sobór watykański II, Dekr. Apostolicam actuositatem, 11.

${ }^{11}$ Warto tutaj przypomnieć o osobie św. Jana Chryzostoma, który rozwijał naukę o rodzinie jako Domowym Kościele. Był kapłanem w Antiochii (386-397), a potem biskupem Konstantynopola (397-407). Z zapałem pisał o wielkiej wartości rodziny. Kierował się niezwykłym wyczuciem teologicznym i duszpasterskim. Wielką rolę odegrało w tej dziedzinie jego osobiste doświadczenie, bowiem w dzieciństwie zaznał ciepła rodziny, a także poznał jej wartość w kształtowaniu wiary. Podstawy teoretyczne kształtowała w nim przede wszystkim Biblia.

${ }^{12}$ FC 57. Por. C. Murawski, Z Boga siła rodziny, Sandomierz 2007, s. 203. 


\section{Wychowanie w rodzinie}

Kontakty między rodzicami i ich stosunek do siebie wywierają istotny wpływ na kształtowanie się osobowości dziecka. Zdania wypowiadane do siebie wzajemnie przez rodziców w obecności dziecka, opinie wyrażane przez nich o ludziach, postawa w sytuacjach szczególnie trudnych formują stopniowo poglądy dziecka, kształtują jego zasady postępowania. To, jak dziecko czuje się w rodzinie, wpływa na jego stosunek do rodziców, na pragnienie podtrzymania kontaktu z nimi bądź dążenie do izolacji od nich ${ }^{13}$. Wychowawcze oddziaływanie rodziców możliwe jest jedynie w warunkach prawidłowej interakcji z dziećmi ${ }^{14}$.

Rodzice winni pamiętać o ważnym zadaniu wychowania dziecka do poczucia godności osoby, o którym tak pisze J. Bagrowicz:

wychowanie do poczucia godności osoby jest wychowaniem do budowania prawidłowej osobowości człowieka. Zaczyna się ono już w okresie prenatalnym, gdy akceptacja dziecka, miłość matki i ojca do życia, które zostało im dane, jest kładzeniem fundamentów pod zdrową osobowość. Akceptacja i miłość otoczenia po narodzeniu dziecka wyraża się najpierw przez bliskość matki i jej stałą obecność. Zaspokojenie wszystkich podstawowych potrzeb dziecka, akceptacja i miłość najbliższych jest budowaniem fundamentów pod właściwe społeczne kontakty dziecka z otoczeniem, a także pod to, co potem nazywa się szacunkiem dla godności człowieka jako takiego. Jeśli matka jest wolna od nieuporządkowanych uczuć, delikatna i akceptująca dziecko, jeśli wczuwa się w reakcje i rytm życia dziecka, to ono reaguje odpowiednio do jej postawy. Mamy wtedy do czynienia z wymianą emocjonalną, rodzi się w dziecku gotowość rezonansu uczuciowego. Mówi się o powstaniu bazy zaufania, o powstawaniu u dziecka prazaufania, o powstawaniu i ugruntowaniu poczucia wspólnoty, więzi z innymi ludźmi, co jest fundamentem zdrowej osobowości ${ }^{15}$.

Warty podkreślenia jest tu charakter dialogicznego wychowania - następuje $\mathrm{w}$ nim dialog pomiędzy rodzicem ( $\mathrm{w}$ tym przypadku jest mowa o matce, ale równie dobrze słowa te mogłyby się odnosić także do ojca) i dzieckiem. Matka rozpoczyna rozmowę, a dziecko przyjmuje informację i odpowiada. To wszystko rozgrywa się na płaszczyźnie emocjonalnej i ma duże znaczenie dla kształtowania się relacji nie tylko ze środowiskiem domowym, ale również ze społeczeństwem. Na rodzicach spoczywa więc wielka odpowiedzialność.

\section{Wychowawcza rola rodziców}

Ksiądz biskup Piotr Bednarczyk słusznie zauważył, iż „wychowanie człowieka to „sztuka nad sztukami”. Wymaga ono nie tylko odpowiedniej wiedzy, talentu pedagogicznego, stosowania właściwych metod, ale także głębokich więzi uczuciowych między wychowawcą a wychowankiem. Wychowanie jest zatem szczególnym

${ }^{13}$ Por. W. Kądziołka, Pedagogiczna i duszpasterska działalność biskupa Piotra Bednarczyka, Kraków 2004, s. 91-92.

${ }^{14}$ Por. M. Grygielski, Style komunikacji rodzicielskiej a identyfikacja dzieci z rodzicami, Lublin 1994, s. 68.

${ }^{15}$ Tamże, s. 210-211. 
typem kontaktów międzyludzkich, połączonym z wywieraniem wpływu przez osobę wychowującą na osobę wychowywaną. Jest to przede wszystkim wpływ osobowości dojrzalszej i bardziej ukształtowanej na osobowość jeszcze nie w pełni uformowaną. Podstawą wpływu wychowawczego jest głęboka i autentyczna relacja osobowa między wychowawcą a wychowankiem. Dlatego słusznie przyrównuje się stosunek wychowawczy do dialogu dwóch osób ${ }^{16}$.

Człowiek, aby stać się tym, kim powinien ostatecznie być, koniecznie potrzebuje wychowania oraz kochających i wymagających zarazem wychowawców. Pozostawiony samemu sobie nie jest bowiem w stanie rozwinąć w pełni swego człowieczeństwa. Prawo i obowiązek rodziców do wychowywania dzieci wypływa z samego faktu przekazania im życia. Jest to pierwsze i pierwszorzędne zadanie w stosunku do innych zadań wychowawczych. Rodzice mają prawo do wychowania dzieci zgodnie ze swoimi przekonaniami moralnymi i religijnymi ${ }^{17}$. Tę prawdę tak często podkreślał bł. papież Jan Paweł II. Był on jednym z największych obrońców małżeństwa i rodziny ${ }^{18}$.

Nawiązując do głoszonych prawd, niestrudzony duszpasterz Kościoła powszechnego i całej rodziny ludzkiej, Ojciec Święty Jan Paweł II, w uroczystość Chrystusa Króla Wszechświata, 22 listopada 1981 roku wydał adhortację apostolską Familiaris consortio - współczesny podręcznik nauczania Kościoła o małżeństwie i rodzinie - poświęcony zadaniom rodziny chrześcijańskiej. Dokument ten jest owocem i ukoronowaniem prac synodu biskupów, który odbył się w Rzymie w dniach od 26 września do 25 października 1980 roku. Ojciec Święty pisze tam między innymi: „do rodziny chrześcijańskiej będzie należała troska o to, by przeżywać swą wspólnotę na modlitwie i w łączności z liturgią Kościoła"19.

Jan Paweł II w adhortacji Familiaris consortio pisze zarówno o prawach czynnych instytucji wychowawczych, jak i o prawach biernych wychowanków ${ }^{20}$. W stosunku do ostatniego wymienia: prawo dziecka do przyjęcia go przez rodzinę i społeczeństwo (prawo do życia), prawo do miłości, prawo do szacunku oraz prawo do wielorakiej i jednolitej służby ze strony dorosłych (materialnej, uczuciowej, wychowawczej i duchowej) ${ }^{21}$.

W dokumencie tym, jak w żadnym dotychczas, papież podjął szeroką problematykę małżeństwa i rodziny. Nie tylko przypomniał w nim naukę Kościoła o tej podstawowej komórce społeczeństwa, ale przede wszystkim Bożą wizję małżeństwa i rodziny nakreślił na tle współczesnej sytuacji, w jakiej się ona znalazła ${ }^{22}$.

\footnotetext{
${ }^{16}$ W. Kądziołka, Pedagogiczna..., s. 71-72.

${ }^{17} \mathrm{FC} 36$.

${ }^{18}$ E. Ozorowski, Stownik malżeństwa i rodziny, Warszawa 1999, s. 118.

${ }^{19}$ Por. FC 61.

${ }^{20}$ J. Korycki, „Familiaris consortio” w kontekście deklaracji o wychowaniu chrześcijańskim, [w:] Wychowanie do miłości, red. K. Majdański, Warszawa 1987, s. 155.

${ }^{21}$ FC 26.

${ }^{22}$ C. Murawski, Z Boga siła rodziny, s. 10.
} 


\section{Macierzyństwo i ojcostwo}

Ojcostwo i macierzyństwo oddziałują na dziecko w sposób zamierzony, czyli poprzez konkretne działanie. Drugą drogą wpływu jest sposób niezamierzony - postawy, zachowania, role przyjmowane przez rodziców ${ }^{23}$.

Pomimo różnic, jakie istnieją pomiędzy dwoma rodzajami rodzicielstwa, są one potrzebne w tym samym stopniu w procesie wychowawczym. Jan Paweł II pisze, iż

należy przede wszystkim podkreślić godność i odpowiedzialność kobiety, również godności i odpowiedzialności mężczyzny. Równość ta realizuje się w szczególności we właściwym małżeństwu i rodzinie dawaniu się drugiemu współmałżonkowi i dawaniu się obojga dzieciom²4.

Rodzice, gdy troszczą się o wychowanie chrześcijańskie, gdy modlą się razem z dziećmi i czytają z nimi słowo Boże, gdy karmią się Ciałem eucharystycznym i dają przykład chrześcijańskich postaw moralnych ${ }^{25}$, „stają się rodzicami w pełni, nie tylko rodzicami życia fizycznego, ale i tego, które przez odrodzenie Ducha Świętego płynie z krzyża i zmartwychwstania Chrystusa"26.

Niepokojącym zjawiskiem jest coraz częstsza bezradność wielu rodziców wobec zadań, jakie stawia przed nimi wychowanie. Sytuacja ta nie dotyczy jedynie rodzin z jakichś powodów dysfunkcyjnych. Warto powołać się na badania dotyczące przyczyn bezradności wychowawczej rodziców ${ }^{27}$. Wynika z nich, iż najlepszą drogą zrehabilitowania bezradności wychowawczej jest dialog, służący wyjaśnieniu wszystkich sytuacji problemowych. Jako główne przyczyny niepowodzeń respondenci wskazywali bowiem najczęściej unikanie rozmów o problemach (96 proc.) oraz brak dialogu (82 proc.).

Wykres 1. Przyczyny bezradności wychowawczej rodziców

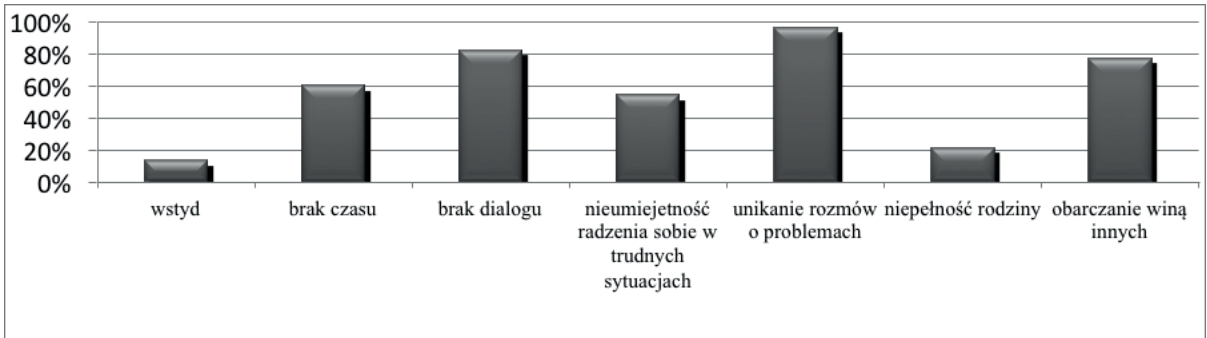

Warto podkreślić, iż rodzice - pierwsi i najważniejsi wychowawcy i nauczyciele swych dzieci - nie muszą być zdani na własne siły. Z pomocą przychodzą im środowiska

\footnotetext{
${ }^{23}$ Por. W. Kądziołka, Rodzina źródtem komunikacji z Bogiem, Kraków 2011, s. 10-15.

${ }^{24} \mathrm{FC} 22$.

${ }^{25}$ J. Korycki, „Familiaris consortio” w kontekście ..., s. 156-157.

${ }^{26} \mathrm{FC} 39$.
}

${ }^{27}$ Ankiety przeprowadzono wśród młodzieży szkół średnich w Krakowie oraz osób dorosłych (studenci studiów zaocznych w Krakowie) w 2011 roku. Łączna liczba respondentów: 500, w tym: 275 - szkoła średnia, 225 - osoby dorosłe. 
odpowiedzialne za dzieło wychowania, m.in. szkoła i Kościół. Wielką nadzieję owocnego wychowania daje bowiem możliwość zgodnej współpracy wszystkich tych środowisk. Żyjemy w czasach, gdy polska rodzina, szkoła i Kościół mogą znów mówić jednym głosem.

Każda matka i każdy ojciec pragną szczęścia swoich dzieci. Jednak pełne szczęście człowiek może odnaleźć jedynie w Bogu. Jest to szczęście, które - zapoczątkowane w ziemskim życiu człowieka - nie kończy się wraz z jego śmiercią. Rodzice, którzy troszczą się o rozwój życia Bożego w sercu własnego dziecka, przekazują mu fundament, na którym będzie mogło się oprzeć całe jego życie, a którego nie zburzą „,deszcze, potoki i wichry” (por. Mt 7, 26-27) życiowych doświadczeń.

\section{Wartości duchowe w procesie wychowania}

Małżeństwo i rodzina uczestniczą w urzeczywistnianiu się Kościoła jako wspólnota życia i miłości. Rzeczywistością małżeństwa i rodziny, a także ich podstawową misją w Ludzie Bożym, jest miłość. Rodzina otrzymuje „misję strzeżenia, objawiania i przekazywania miłości, będącej żywym odbiciem i rzeczywistym udzielaniem się miłości Bożej ludzkości oraz miłości Chrystusa Pana Kościoła, Jego oblubienicy”28. Wyrastają stąd cztery podstawowe zadania małżeństwa i rodziny chrześcijańskiej, sformułowane przez Jana Pawła II w adhortacji Familiaris consortio. Zadaniami tymi są: tworzenie wspólnoty osób, służba życiu, udział w rozwoju społeczeństwa i uczestnictwo w życiu i posłannictwie Kościoła ${ }^{29}$.

Człowiek jako istota cielesno-duchowa potrzebuje wartości duchowych ${ }^{30}$. Może mu je zapewnić życie we wspólnocie z innymi. Jan Paweł II w adhortacji Familiaris consortio napisal:

W rodzinie bowiem osoba ludzka nie tylko rodzi się i stopniowo, poprzez wychowanie, wprowadzana jest we wspólnotę ludzką, ale także [...] poprzez wychowanie w wierze wprowadzana jest w rodzinę Bożą

Działanie moralne człowieka zależy od wspólnoty. Dzięki życiu w niej człowiek staje się uczestnikiem i twórcą wartości moralnych, które noszą cechy moralności wspólnotowej. Taki zaś charakter moralności ludzkiej decyduje o odpowiedniej interpretacji wymagań natury i wynikającego z niej prawa moralnego ${ }^{32}$.

\footnotetext{
${ }^{28} \mathrm{FC} 17$.

${ }^{29}$ E. Ozorowski, Stownik..., s. 12.

${ }^{30}$ Por. W. Kądziołka, Rodzina ..., s. 29-30.

${ }^{31} \mathrm{FC} 15$.

${ }^{32}$ T. Borutka, Społeczne nauczanie kościoła, Teoria i zastosowanie, Kraków 2004, s. 100.
} 


\section{Wychowanie seksualne}

W wychowaniu seksualnym, o którym mowa w Familiaris consortio, należy odwoływać się do fundamentalnych prawd ludzkiego życia. Tak rozumiane wychowanie seksualne wchodzi w zakres wychowania do miłości, który wiąże się z najważniejszymi problemami ludzkiego życia - z jego sensem i celem, z ideałami i wartościami. Zakłada ono takie przygotowanie młodego człowieka, aby w sposób odpowiedzialny realizował swoją płciowość w oparciu o poszanowanie ogólnoludzkich wartości. Ponadto jest kształtowaniem i rozwijaniem w człowieku zdolności i motywacji do samowychowania, do kierowania swoim życiem. Takie wychowanie obejmuje szczególną troską rozwój uczuciowy, stanowiący podstawę prawidłowej postawy wobec samego siebie i drugiego człowieka, umożliwiający nawiązywanie głębokich więzi z innymi. Tylko działania wychowawcze, wolne od płytkich technik i instruktaży antykoncepcyjnych, pomagają młodzieży w poszukiwaniu ideałów, ukierunkowują kształtowanie postawy miłości, umożliwiają właściwą integrację wszystkich wymiarów osobowości.

Właściwie rozumiane wychowanie seksualne ${ }^{33}$ wymaga tego, aby rodzice i wychowawcy dostrzegali w każdym człowieku, niezależnie od płci i wieku, godność osoby ${ }^{34}$.

Wychowanie seksualne, stanowiące prawo i podstawowy obowiązek rodziców, „winno dokonywać się zawsze pod ich troskliwym kierunkiem, zarówno w domu, jak i w wybranych przez nich ośrodkach wychowawczych" ${ }^{35}$. Choć dokumenty Kościoła jasno określają zakres tego wychowania, to jednak w praktyce pojawiają się różne interpretacje dotyczące celu tego wychowania, czy też stosowanych metod, a także osób, które mogą podejmować działalność wychowawczą w tym zakresie. Niestety, proponowane są tu liczne programy nieuwzględniające integralnej wizji człowieka. Dla odróżnienia, dokumenty kościelne na ich określenie używają terminu „edukacja seksualna”.

Obowiązek wychowawczy rodziców ma szczególne znaczenie w odniesieniu do ludzkiej płciowości. Wychowanie seksualne stanowi prawo i podstawowy obowiązek rodziców ${ }^{36}$. Wychowanie to ma doprowadzić do znajomości zasad moralnych i uznania ich za niezbędne dla odpowiedzialnego wzrostu osobowego w dziedzinie płciowości ludzkiej. Ma ono także zaznajomić ze stroną biologiczną i psychologiczną tej sfery ludzkiej osobowości.

${ }^{33}$ K. Ostrowska, Edukacja czy wychowanie seksualne, ,Studia nad Rodziną” 1 : 1998, s. 149-162.

${ }^{34}$ Pojęcie osoby związane jest nierozerwalnie z personalizmem. Słowo „,personalizm” pochodzi od łacińskiego słowa persona oznaczającego „osoba”. Personalizm to kierunek, który zaakceptował do końca konsekwentnie wartość samego człowieka, jako osoby i osobowości, a rozwój tej osobowości uczynił podstawową, autonomiczną wartością i celem działań. Podstawowym aksjomatem, na którym opiera się nurt myślenia zwany personalizmem, jest prawda mówiąca o tym, że człowiek jest osobą.

${ }^{35} \mathrm{FC} 27$.

${ }^{36}$ Por. tamże. 
Ze względu na różne trudności, na jakie natrafiają w obecnych czasach rodzice (m.in. rozpowszechniana przez mass media pornografia), konieczna jest $\mathrm{z}$ ich strony podwójna troska: „z jednej strony wychowanie dzieci uprzedzające i krytyczne, z drugiej - odważne demaskowanie niewłaściwych poczynań władz" ${ }^{\prime 37}$.

Biorąc pod uwagę etapy rozwoju dziecka, rodzice w wychowaniu seksualnym powinni brać pod uwagę cztery ogólne zasady: 1) każde dziecko, jako osoba jedyna i niepowtarzalna, powinno otrzymać indywidualną formację; 2) wszystkie przekazywane młodym wyjaśnienia zawsze powinny posiadać wymiar moralny; 3) wychowanie do czystości i udzielanie stosownych informacji na temat ludzkiej płciowości powinno dokonywać się w szerszym kontekście wychowania do miłości; 4) rodzice powinni przekazywać te informacje z najwyższą delikatnością, ale w sposób jasny i we właściwym czasie ${ }^{38}$.

\section{Kryzys wzorców wychowawczych}

Jan Paweł II w adhortacji Familiaris consortio przedstawił szeroki zespół zagadnień, poczynając od naszkicowania sytuacji, w jakiej znalazła się rodzina, poprzez przedstawienie zamysłu Bożego względem tej podstawowej wspólnoty, aby następnie ukazać jej zadania i sposoby ich realizacji we współczesnym Kościele i w świecie ${ }^{39}$.

Jednakże dokonujące się na naszych oczach zmiany cywilizacyjne i kulturowe doprowadziły do zachwiania tradycyjnych wzorców wychowawczych. Nasi przodkowie w sposób oczywisty „dziedziczyli” wartości i metody pedagogiczne swych rodziców i dziadków, przekazując je następnym pokoleniom. Prości ojcowie i matki, nie korzystając ze specjalnych poradników pedagogicznych, a kierując się jedynie rodzicielską miłością i mądrością, potrafili pomóc swym dzieciom stać się dojrzałymi i szlachetnymi ludźmi. Świadczą o tym ludzkie historie, a wśród nich piękne życiorysy świętych.

Dziś ten naturalny proces napotyka na wiele przeszkód. Jedną z nich jest rosnące tempo życia. Mamy coraz mniej czasu dla siebie i swoich bliskich. Wielu rodziców pochłoniętych pracą zawodową zmuszonych jest powierzać swoje dzieci przez sporą część dnia opiece innych osób czy instytucji. A przecież nawet najbardziej oddany i troskliwy opiekun nie zastąpi kontaktu dziecka z ojcem i matką. Jeszcze trudniejsza z wychowawczego punktu widzenia jest sytuacja rozłąki rodziców $\mathrm{z}$ dziećmi spowodowana np. pracą za granicą. Czas poświęcony przez rodziców swoim dzieciom od pierwszych chwil ich życia jest nie do zastąpienia.

${ }^{37}$ Papieska Rada ds. Rodziny, Ludzka płciowość: prawda i znaczenie. Wskazania dla wychowania w rodzinie, Watykan 1995, 45.

${ }^{38}$ Por. Papieska Rada ds. Rodziny, Ludzka ptciowość: prawda i znaczenie. Wskazania dla wychowania w rodzinie, Łomianki 1996, s. 65-75.

${ }^{39}$ C. Murawski, Z Boga siła rodziny, s. 286. 
Warto odwołać się do analizy danych dotyczących wzorców wychowawczych, z których korzystają respondenci w swoich rodzinach.

Wykres 2. Jakie wzorce wychowawcze przeważają w Pana/Pani rodzinie?

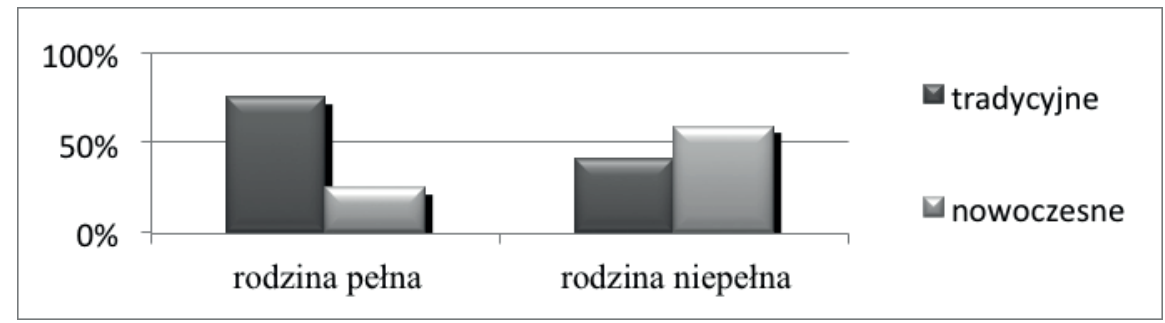

Z przeprowadzonych badań wynika, iż w rodzinie pełnej zdecydowana większość, bo 75 proc. respondentów korzysta z tradycyjnych wzorców wychowawczych. W przypadku rodzin niepełnych ${ }^{40}$ taką sytuację odnotowano u 59 proc. badanych. Za nowoczesnym wzorcem wychowania opowiedziało się 25 proc. respondentów $\mathrm{z}$ rodzin pełnych i 41 proc. $\mathrm{z}$ rodzin niepełnych.

Dla lepszego zobrazowania omawianego zjawiska, warto przytoczyć kilka wypowiedzi respondentów dotyczących wzorców wychowawczych, z których czerpią ich rodziny:

Dla mnie rodzina kojarzy się z ciepłem i miłością, czasem poświęconym na wspólną rozmowę, spożywanie posiłków. Nikt nie może nie czuć się nieakceptowany.

Rodzice wychowali mnie na osobę prawą i uczciwą, jednak szybko zorientowałam się, iż ten model wychowania nie jest odpowiedni dla czasów, w jakich żyjemy. Obecnie ludzie żyją bardzo szybko, nie mają czasu na pielęgnowanie tradycji i spokojną rozmowę. Wiem, że sposób, w jaki wychowali mnie rodzice, przyniósłby moim dzieciom więcej szkód niż korzyści, dlatego postanowiłam unowocześnić model wychowania stosowany w mojej rodzinie.

Pochodzę z rodziny rozbitej, gdzie nie przywiązywano dużej wagi do podtrzymywania tradycji. Zawsze zazdrościłam koleżankom rodzinnej atmosfery podczas świąt, wspólnych wypadów do kina czy na wycieczki z rodzicami. U mnie nie było na to czasu i pieniędzy, mama ciągle pracowała, by starczyło nam do pierwszego. Wychowałam się właściwie sama, ale nie pozwolę, by moje dzieci też musiały przez to przechodzić.

Tradycyjny model wychowania jest już przestarzały. Nie oszukujmy się - technika idzie do przodu, czasy się zmieniają, inne wartości są piętnowane. Chyba mało który rodzic będzie karał swoje dziecko za piętnastominutowe spóźnienie po powrocie z imprezy. A za moich czasów nikt nie odważyłby się nawet spóźnić.

Jedyną szansą na stworzenie prawdziwej rodziny jest sięganie do tradycji. Rodzice wychowali

${ }^{40} \mathrm{~W}$ celu dokonania analizy respondenci zostali poddani pewnej selekcji. Podzielono ich na respondentów żyjących w danej chwili (poprzez sformułowanie „w danej chwili” należy rozumieć, że w chwili przeprowadzenia badań, respondent znajdował się w takiej sytuacji rodzinnej) w rodzinach pełnych (czyli rodzice i dzieci mieszkający razem) i rodzinach niepełnych (czyli jedno z rodziców nie mieszka z rodziną ze względu na wyjazd za granice państwa lub do innego miasta w celach zarobkowych, lub z uwagi na inną sytuację rodzinną). 
mnie na bogobojną osobę, nauczyli mnie poszanowania dla religii i ludzi. Dzięki nim osiągnęłam w życiu tak dużo.

Jan Paweł II w adhortacji Familiaris consortio stwierdza, że człowiek jako osoba sam w sobie jest powołany do wzrostu i rozwoju ${ }^{41}$. Rodzice, którzy rodzą nową osobę „W miłości i dla miłości, tym samym podejmują zadanie umożliwienia jej życia w pełni ludzkiego"42. To zaś życie opiera się na godnym korzystaniu z możliwości specyficznie ludzkich, które łączą się z rozwojem intelektualnym, wolnością, twórczością, ocenami moralnymi i naturalną otwartością osoby na poznanie i miłowanie $\mathrm{Boga}^{43}$. Główną rolę w dynamizowaniu tego naturalnego rozwoju odgrywa rodzina ${ }^{44}$.

W omawianej adhortacji papież podkreśla, że troska o wychowanie chrześcijańskie to troska o wzrost w wychowanku „dziecka Bożego, brata Chrystusa, świątyni Ducha Świętego, członka Kościoła"45. Te zaszczytne zadania wychowania chrześcijańskiego realizują się przez naśladowanie na co dzień Chrystusa. Szkołą tego naśladowania ma być rodzina ${ }^{46}$. W niej bowiem mogą zaistnieć warunki, w których na zasadzie sprzężenia zwrotnego „wszyscy członkowie ewangelizują, a także podlegają ewangelizacji”"

Wychowanie chrześcijańskie zawiera element społeczny, wolność i odpowiedzialność, troskę o dobro wspólne i o pokój, uznanie dla postępu nauki i techniki, dążność do chrześcijańskiego ukształtowania świata, dialog z ludźmi o przekonaniach odmiennych itp.

Sposób przekazu winien być dostosowany w treści i języku do wieku i etapu rozwojowego. Na pytania dziecka rodzice winni odpowiadać zgodnie z prawdą. Potrzebna jest tu otwartość rodziców, ich chęć szczerej rozmowy, która odbywa się w klimacie zaufania. W tym aspekcie konieczne jest życie głoszonymi prawdami, autentyczność, dojrzałość, przekonanie dzieci, że zawsze mogą liczyć na rodziców ${ }^{48}$. Modelem, który pragnie służyć i iść z każdą rodziną ,krok w krok na różnych etapach jej formacji i rozwoju"49 niech będzie święta Rodzina z Nazaretu.

Każdy człowiek, który pragnie założyć własną rodzinę, winien dokładnie przemyśleć i zrozumieć, że ,rodzina to wspólnota dwóch osób, mężczyzny i kobiety, oparta na miłości

${ }^{41} \mathrm{FC} 36$.

42 Tamże.

${ }^{43}$ J. Korycki, „Familiaris consortio” w kontekście..., s. 155-156.

${ }^{44} \mathrm{FC} 37$.

${ }^{45}$ FC 39.

${ }^{46}$ Tamże.

${ }^{47}$ Tamże; Paweł VI, Adh. Evangelii nuntiandi, 71; „Acta Apostolicae Sedis” 68 : 1976, s. 60n.

${ }^{48}$ D. Kornas-Biela, Historyczny kontekst rozwoju edukacji seksualnej i jej konsekwencje, ,, Studia nad Rodziną" 1 : 1998, s. 133-148.

${ }^{49}$ Tamże. 
i wolnym wyborze, gdzie połączeni węzłem małżeństwa, wzajemnie odpowiadając za siebie, decydują się na prokreację, opiekę i wychowanie swoich dzieci" ${ }^{50}$.

\section{Summary}

\section{Educational dialogue's faces in apostolic adhortation "Familiaris consortio" against upbringing in family}

This article is concentrated on educational dialogue which is one of the most important thing for upbringing in family. Young people need to speak with their parents about everything without communicational barriers because it is the only one guarantee that they will have good contacts with other people. Sexual education in family should not be a theme taboo. Parents ought to be no forbidden subject in family. They should bring up their children in religious atmosphere because in this model they will know both advantages and disadvantages of taking some decisions which should be responsible. Parents should speak with their children especially about spiritual values which are very often omit in everyday life on benefit safe and trite conversations.

Family has got special apostolic mission. It must have been the first and vital cell of society. In this way, it must have been a home sanctuary of the Church, too. John Paul II was talking many times that family is the first place where kids can teach a suitable procedure and correct communication which have influence on their life in the future.

Despite of being a crisis of educational patterns, parents have to remember that both of them have got their own educational tasks to create of proper educational atmosphere in family.

\section{Keywords}

Apostolic Adhortation Familiaris Consortio, Catholic Church, child, dialogue, education, family, parent 
